This article has been scanned by iThenticat No plagiarism detected

Volume 3, Issue 6, December 2021

p. 467-479

\title{
CRITERIA FOR IMPROVING THE QUALITY OF THE BIOLOGY TEXTBOOK FOR THE SCIENTIFIC SIXTH GRADE (AN EVALUATION STUDY)
}

http://dx.doi.org/10.47832/2757-5403.6-3.35

\begin{abstract}
:
This research aims to build criteria for improving the text book quality and to Identify the extent in which criteria might be implied in the Biology textbook, might be implied in the Biology textbook for the 6th Grade, to achieve the research objectives, the researcher depend on the description method and the questionnaire as the research instrument which consisted of (7) fields: the introduction, the educational objectives, the scientific content, the activities, the photos - figures tables, the evaluation methods, the artistic editing.

It includes (99) criteria. Reliability and validity have been affirmed. The number of individuals is (1950) and the sample of the research is (331) as teachers and s supervisors for biology, they were chosen randomly who represented the Iraqi governorates of 2017.

The research has concluded that the biology textbook has achieved most of quality criteria with admission of weakness in criteria of introduction and activities. The researcher recommends to adopt criteria of textbook quality which adopted by this research and to reconsider the reorganizing the textbook and to take in consideration of the practical aspect.

The researcher suggests to $\mathrm{n}$ evolutions to other Biology Textbook to get the specialties in authorizing Textbooks.
\end{abstract}

Key words: Criteria, Improving, Total Quality, Book Quality, Textbook, Evaluation.

\footnotetext{
${ }^{1}$ Dr. , Ministry of Education, Iraq, drhusseinmakawen15@gmail.com
}

Copyright $($ Published by IJHER Journal, www.ijherjournal.com Rimar Academy, Fatih, Istanbul, 34093 Turkey

All rights reserved 


\section{Introduction}

Education is a human, social, cultural, and scientific process that attracts the attention of researchers, in order to bring about the development of its components (philosophy, policies, curricula, goals, methods, etc.), (Khawaldeh 2007: 11). In order for education to achieve its goals as an organized and dynamic process, it must rely on curricula that reflect its philosophy. Since the textbook is the true container for the content of the curriculum, and a ruling reference between the student, the teacher, the supervisor and the school; therefore, it must be improved and refined according to the comprehensive quality standards represented by its main elements (continuous improvement, effectiveness, and efficiency), imposed by the movement of life, and meets the needs of students and the school, the curriculum represents the desired experiences that the school provides to its students under its supervision in order to build their personalities, with the cooperation of partners in the institution in its various fields in improving and refining the book. (Deming, $1986,88)$, The curriculum is no longer a set of consecutive courses in a specific field of study (Oliva, 2008, 18), Because the textbook is one of the main sources of knowledge that the teacher adopts in the planning, implementation and evaluation processes that students cannot be dispensed with to perform their educational duties. This requires building clear standards for advancement By, (Obaidat, 1999, 45), Therefore, it should be subject to continuous and comprehensive evaluation and improvement processes, as it relates to the student's life, to see the extent to which it includes quality standards for improving the book.

The fields of quality improvement standards should be balanced in the textbook and included in it. Therefore, evaluation processes were conducted, by polling (80) teachers and supervisors in Egypt to find out about the level of quality standards in the physics book for the fifth grade of middle school, As first came the field of artistic editing, followed by the content of the book, then the privacy of the material, but there is a problem with the style of writing and displaying the content. (Al-Ashqar et al., 2007), by analyzing the science book for the first intermediate grade (seventh level) in the Kingdom of Saudi Arabia to see the extent to which it achieved comprehensive quality standards in its basic aspects, the book included the standards of editing quality, quality of goals, content quality, and evaluation methods, respectively. But there is weakness in cover design, and lack of interest in the emotional side (Asilan 2011), In Iraq, the evaluation of the physics textbook for the fourth grade of science showed in accordance with comprehensive quality standards from the point of view of (126) teachers and supervisors. (Harpah et al., 2015), It school that it achieved such criteria with different aspects with a problem in building goals and building activities. There is a weakness in matching with scientific development. The increasing of the book size.

Because of the importance of the sixth grade of middle school as the end of the general education stage, it aims to prepare students for university education. The process of improving and developing the textbook requires its inclusion of international quality standards, This scientific attempt is adopted as the absence of such studies that adopts its evaluation according to the quality criteria of the book. To provide a benefit for biology teachers in identifying the book's quality standards, the study provides a curriculum for decision makers in the Ministry of Education and curriculum others to develop the current book. With the aim of building a system of standards for the quality of the textbook, and getting to know what it actually contains of those standards from the point of view of biology teachers for the sixth scientific class and the supervisors in the governorates of Iraq, Since they are more experience in this field. Collecting, classifying, analyzing and interpreting data in terms of quantity and quality in order to pass judgment on improving the textbook. (Ali, 2007, 233). and the availability of standards for improving the quality of biology for the sixth grade, which are intended as a tool for current research. As an integrated system that 
includes a set of its elements to help students and teachers for the subject matter to achieve the desired goals. (Meri and Muhammad, 2011, 251). The organization according to a special format to benefit from it to a specific educational level because it is a source of information. (Good, 1973, 51). And the one who is responsible for authorizing textbooks in Iraq is the General Directorate of Curricula / Ministry of Education. The sixth year of middle school (12) is the last academic year of the high school / scientific branch, which allows the student to continue university studies or prepare students for life. (Ministry of Education, 1984) The evaluation according to a group of arbitrators will be a basis for judging by comparing it with what is available in order to reach strengths and weakness points that need improvement.(Good, 1973: 153), To make the book in the best specifications, and on the basis of which a judgment is issued (Yusef, 2004, 504), according to a special questionnaire, with the aim of including those criteria in the book, which is a goal that is sought to be accomplished by making continuous efforts. (Hariri, 2011, 265). And to provide a product or service of excellent quality to meet the needs and requirements of the customer at the lowest cost. (Ben Chlouia, and Sharafi, 2013, 28) According to the opinions of specialized teachers and supervisors, a process of evaluating and developing its elements and foundations should be conducted to make it more capable of achieving the desired goals according to predetermined standards. (Hamat, 2009, 199), And to diagnose learning styles in an organized, planned, continuous and integrated manner, and to provide indicators of its effectiveness and methods of teaching it and passing judgments based on appropriate and multiple evaluation tools. (Olayyan, 2010, 161), It should be built in a thoughtful way in terms of artistic production and organizing scientific content in a way that suits the cognitive, skill, educational and psychological aspect, to become an effective tool that facilitates the educational-learning process, and contributes to achieving the desired goals to build a learner capable of facing cognitive, technological and social developments. (Khawaldeh, 2004, 301), Edwards Deming is one of the most important pioneers of quality and criteria application, who asserted that quality is the degree of excellence that can be predicted by using more appropriate and less expensive standards, in cooperation with the beneficiary, and shows its effects on the final product or service provided. (Taima, et al., $2006,25)$, The process of internal review of programs for quality assurance is mediated by internal and external arbitrators. (Al-Qadat and Al-Khawaldeh, 2016, 12), This requires a set of standards and indicators for aspects of the educational process, and their effective application. They represent the desired level that education graduates seek to reach according to specific indicators of the level of knowledge, skills and values. (Malkova, 1989: 36).

Adopting these standards provides diagnostic data for teachers to evaluate curricula, plan teaching and adapt content, adopt effective teaching strategies, and provide feedback to students as an indicator of their progress. (Toaima et al., 2006, 23-24), as well as developing the quality of the textbook and the service provided, raising the level of performance of curriculum authors and teachers, continuous methods, performance and methods, reducing product costs, developing employee loyalty to an institution and continuing growth and competition (Dahdouh, 2018, 44). ).

The researcher believes that the quality criteria for improving the textbook lies in its importance in determining its current level for the purpose of improving it in the future, defining its objectives, presenting a clear common language in the presentation of the content, and making real judgments about its refinement by teachers and encouraging them as field specialists. Improving schoolbook quality standards depends on a set of principles, including: Long-term planning to organize the institution's work and ways to achieve its view, mission, goals and strategy. Support and encourage the higher management of the institution and allocate resources to satisfy customers and service recipients. Continuous improvement of system design and implementation will achieve customer satisfaction and 
training and education of the team, motivating them and enhancing their knowledge and abilities to improve work and services and solve problems. According to building standards to measure the quality to improve it better. (Abdullah, 2015, 168-169) to clarify and correct the scientific content, and the way to build and organize it, in a way that helps students solve the problems they face and produce their knowledge (Iztok \& Janez, 2013, 8-9).

One of the most important elements of the textbook is the scientific content. So scientific content standards should be built because it determines what the student should know and understand during his study period in terms of concepts, processes, methods of investigation, and the nature of science from a personal and social perspective. (Harris, $2001,5)$, as well as the quality of the artistic production in terms of cover, size and type of letters. The researcher believes that the importance of the textbook lies in the quality of its content and the service it provides to students, teachers and society, and the extent of its competition for textbooks in the educational systems of other countries. This requires developing the capabilities of curriculum authors through specific training to build standards that can be relied upon to improve the authoring mechanism and encourage creativity. And developing students' abilities and desired values, and drawing a road map for teachers to enable them to perform their roles in the best way. Therefore, the opinions of teachers and supervisors will be approved through a questionnaire as a way to conduct the research.

\section{Research Methodology 5.5 materials and Research methods}

To achieve the two objectives of the research, a descriptive and field-analytical approach was adopted, to identify the views of the community consisting of (1950) teachers of the biology subject for the sixth scientific / biological preparatory grade, 296 of them were chosen as a research sample, representing (15.18\%), and (87) supervisors. (35) supervisors, representing $(40.23 \%)$, were chosen randomly (by the general directorates of education in the governorates), (Ministry of Education, 2017). After reviewing the previous studies and related literature, the researcher prepared a questionnaire as a primary tool for research for its objectivity to obtain data and verify its validity to measure what it was actually prepared to measure (Abbas et al. 2011: 261). The tool included (102) criteria distributed into seven fields, and it was verified that Its apparent validity by depending on the opinions of the arbitrators about the extent to which the items represent the characteristic to be measured, (Eble, 1972, 667), the questionnaire was distributed to (10) arbitrators specialized in the educational and psychological field, curricula, teaching methods, quality, measurement and evaluation, (Appendix 1), For the purpose of determining the validity of those criteria, and proposing what they see (amendment, deletion, addition, or integration of some criteria). Three alternatives were placed before each criterion (valid, invalid, needing to be modified).It was based on an agreement percentage $(80 \%)$ of their opinions regarding the validity of criteria. The percentage of agreement $(80 \%)$ or more between the arbitrators is evidence of the apparent validity of the tool (Blume, 1983, 226), Amendments were made according to their opinions and some criteria were integrated. Two workshops were held for the authors of the curricula, in which the criteria of the questionnaire were presented, The participants expressed their opinions and suggestions, and the tool in its final form included (99) criteria distributed into seven fields, and used the (Liker) five-point scale for the purpose of the questioners' answers: (included to a very much, moderate, sometimes and not included). The numerical values were given to them respectively $(5,4,3,2,1)$. The questionnaires were distributed to teachers of biology subject participating in one of the training courses held at the General Directorate of Teacher training and Educational Development of (28) teachers, to indicate any difficulty they face when answering the items of the questionnaire. It was very clear. The questionnaire was applied again 10 days after the first application on the members of the same survey sample. Since the validity of the questionnaire as a valid tool 
should give the same results, if it is re-applied on the same sample members (Odeh, 1992, 345). By using the Pearson correlation Equation the result was good indicator.

After affirming the questionnaire items of the validity and reliability it was distributed to the sample participants (331) teachers and supervisors. The questionnaires were returned after answering its items.

The researcher used a set of required statistical methods: (frequency, weighted mean, weight percentage., Pearson correlation coefficient).

\section{View results (Results presentation)}

The first aim: To verify the first aim of the research which states (building standards to improve the quality of the textbook), the researcher constructed a questionnaire of criteria for improving the quality of the biology textbook for the sixth grade scientific, including (99) criteria distributed into (seven) filed that include improving the quality of each of Introduction: Includes (10) criteria, educational aims which includes (10) criteria, scientific content which includes (20) criteria, activities which includes (15) criteria, pictures, figures and tables which includes. (12) criteria, evaluation methods and includes (15) criteria, artistic editing which Includes (15) criteria\}. Thus, the first aim of the research was achieved.

The second aim: To achieve the second aim of the research which was stated (identifying the quality improvement criteria included in the biology textbook for the sixth grade scientific): The weighted mean and percentage weight for each item and for each filed. They were arranged extracted together, according to the descending order of the percentage weight of the criteria that are equal to or higher than the arithmetic mean of the percentage weights of the item for each field are included as well included in the biology textbook, the average of the arithmetic averages for the seven filed was (65.09). As shown in Table (1)

Table (1) Explains the fields of text book quality criteria and number weights of criteria for each field and arithmetic mean for percentage of field item and their grades

\begin{tabular}{|l|l|l|l|l|}
\hline Ser. & $\begin{array}{l}\text { grad } \\
\text { e }\end{array}$ & The field & $\begin{array}{l}\text { No. } \\
\text { criteria }\end{array}$ & $\begin{array}{l}\text { Arithmetic } \\
\text { Mean }\end{array}$ \\
\hline 7 & 1 & Quality improvement of artistic editing & 15 & 73.06 \\
\hline 5 & 2 & $\begin{array}{l}\text { Quality improvement of photos, figures and } \\
\text { tables }\end{array}$ & 12 & 66.57 \\
\hline 2 & 3 & Quality improvement of Education objectives & 10 & 65.26 \\
\hline 6 & 4 & Quality improvement of evaluation methods & 15 & 65.22 \\
\hline 3 & 5 & Quality improvement of scientific content & 22 & 63.55 \\
\hline 1 & 6 & Quality improvement of introduction & 10 & 62.72 \\
\hline 4 & 7 & Quality improvement of activities & 15 & 59.25 \\
\hline \multicolumn{7}{|l|}{ The sum and the arithmetic mean } & 99 & 65.09 \\
\hline
\end{tabular}

Tables (2-8) show that:

Table (2) explain as the answers of the sample for the field of criteria introduction quality

\begin{tabular}{|l|l|l|l|l|}
\hline Ser. & grade & criteria & $\begin{array}{l}\text { Weighted } \\
\text { average }\end{array}$ & $\begin{array}{l}\text { Percentage } \\
\text { Weight }\end{array}$ \\
\hline 3 & 1 & Indicates the general objectives of the book & 3.48 & 69.61 \\
\hline 5 & 2 & Showing the theoretical basis of the book. & 3.38 & 67.61 \\
\hline 1 & 3 & The introduction shows the text book importance & 3.33 & 66.65 \\
\hline 6 & 4 & Explains how to distribute the content & 3.27 & 65.38 \\
\hline 2 & 5 & Includes the book philosophy & 1.24 & 64.89 \\
\hline 4 & 6 & The book Philosophy is in accord with the world & 3.11 & 62.24 \\
\hline
\end{tabular}




\begin{tabular}{|l|l|l|l|l|}
\hline & & modern trends of education & & \\
\hline 10 & 7 & $\begin{array}{l}\text { Evokes the students motivation to study the book } \\
\text { subjects }\end{array}$ & 3.01 & 60.12 \\
\hline 7 & 8 & $\begin{array}{l}\text { Indicates the method of teaching the scientific } \\
\text { content }\end{array}$ & 2.97 & 59.34 \\
\hline 9 & 9 & $\begin{array}{l}\text { The book Philosophy calls for meeting the needs } \\
\text { of the students and society. }\end{array}$ & 2.91 & 53.19 \\
\hline 8 & 10 & Supports national affiliation & 2.66 & 53.17 \\
\hline \multicolumn{2}{|l|}{ |rithmetic mean for the field of items weight } & 3.14 & 62.72 \\
\hline
\end{tabular}

Table (2) shows that the scope for improving the quality of the introduction was ranked sixth, with an arithmetic mean of (62.72). The following criteria were included in the book with a high degree. Criterion 3 came first (indicating the general objectives of the book), followed by criterion 5 (Showing the theoretical basis of the book). Then criterion 1 (showing the importance of the textbook), followed by criterion 6 (illustrating how to distribute the scientific content), then criterion 2 (includes the philosophy of the book). The introduction referred to the objectives of the book and the importance of its study and the mechanism of distributing its chapters and content. Other criteria were included with a medium and weak degree, and this may be due to the authors lack of interest in the introduction of the book despite its existence, because it has no importance in the ministerial exams for the preparatory stage.

Table (3) shows the responses of teachers and supervisors to the scope of criteria for improving the quality of educational objectives

\begin{tabular}{|c|c|c|c|c|}
\hline Ser. & grade & criteria & $\begin{array}{l}\text { Weighted } \\
\text { average }\end{array}$ & $\begin{array}{l}\text { Percentage } \\
\text { Weight }\end{array}$ \\
\hline 14 & 1 & $\begin{array}{l}\text { The aims include the levels of the knowledge domain: } \\
\text { remembering, understanding, application, analysis, } \\
\text { synthesis, evaluation) }\end{array}$ & 3.50 & 69.97 \\
\hline 19 & 2 & Suit the scientific and activity content & 3.43 & 68.58 \\
\hline 11 & 3 & Agree with education philosophy and objectives & 3.36 & 67.31 \\
\hline 18 & 4 & Observable and measurable & 3.30 & 65.92 \\
\hline 15 & 5 & $\begin{array}{l}\text { Develop the trends and directions desired by the } \\
\text { students }\end{array}$ & 3.23 & 64.59 \\
\hline 13 & 6 & Take into account the students, individual differences & 3.22 & 64.41 \\
\hline 16 & 7 & Related to the future requirements of the society & 3.17 & 63.44 \\
\hline 12 & 8 & $\begin{array}{l}\text { Balances the fields of cognitive, emotional and skilled } \\
\text { objectives }\end{array}$ & 3.17 & 63.38 \\
\hline 17 & 9 & $\begin{array}{l}\text { Develop the students' abilities in thinking and } \\
\text { innovation }\end{array}$ & 3.15 & 63.02 \\
\hline 20 & 10 & In accordance with the students' needs and trends & 3.11 & 62.11 \\
\hline \multicolumn{3}{|c|}{ Arithmetic mean for the field of items weight } & 3.26 & 62.26 \\
\hline
\end{tabular}

Table (3) show that The educational aims scope ranked third with arithmetic mean of (65.26). The book included the following criteria to a high degree, as came first criterion 14 (the aims include the levels of the knowledge domain: remembering, understanding, application, analysis, synthesis, evaluation), followed by criterion 19 (compatible with scientific content and activities), and third came criterion 11 (consistent with Philosophy and objectives of education), followed by Standard 18 (observable and measurable), This is due to the reliance of education in Iraq on the knowledge field and according to Bloom's classification in the first place, and the connection of the scientific content with the accompanying activities, the philosophy of education, the objectives were clearly formulated 
at the beginning of each chapter. The other criteria were graded at a medium and weak degree. This indicates the book's interest in knowledge educational aims on the behalf of the emotional skill field, and thinking.

Table (4) shows the responses of a sample of teachers and supervisors to the field of scientific content quality standards

\begin{tabular}{|c|c|c|c|c|}
\hline Ser. & grade & criteria & $\begin{array}{l}\text { Weighted } \\
\text { average }\end{array}$ & $\begin{array}{l}\text { Percentage } \\
\text { Weight }\end{array}$ \\
\hline 24 & 1 & Suitable with the students level and mental abilities & 3.47 & 69.49 \\
\hline 31 & 2 & $\begin{array}{l}\text { Its presentation implies the suitable methods of } \\
\text { teaching }\end{array}$ & 3.44 & 68.70 \\
\hline 34 & 3 & Without repetition and elaboration & 3.33 & 66.59 \\
\hline 23 & 4 & $\begin{array}{l}\text { The size is suitable with number of lessons approved } \\
\text { in teaching plans }\end{array}$ & 3.33 & 66.53 \\
\hline 22 & 5 & Achieves Education objectives & 3.32 & 66.28 \\
\hline 21 & 6 & $\begin{array}{l}\text { Matching with the philosophy of the book and } \\
\text { society }\end{array}$ & 3.31 & 64.28 \\
\hline 27 & 7 & $\begin{array}{l}\text { It is distinguished by scientific and technical } \\
\text { modernity }\end{array}$ & 3.31 & 64.17 \\
\hline 36 & 8 & Includes illustrative examples and proofs & 3.27 & 64.05 \\
\hline 32 & 9 & $\begin{array}{l}\text { Develops the student innovation ability and skills of } \\
\text { scientific thinking }\end{array}$ & 3.21 & 63.75 \\
\hline 29 & 10 & $\begin{array}{l}\text { Takes into account experiences of students and } \\
\text { integrated with the previous them }\end{array}$ & 3.20 & 63.14 \\
\hline 37 & 11 & $\begin{array}{l}\text { Taking into account principle of flexibility, } \\
\text { amenability }\end{array}$ & 3.19 & 63.14 \\
\hline 28 & 12 & Related to life attitudes and environmental problems & 3.16 & 62.94 \\
\hline 30 & 13 & Introduces the material in exciting way & 3.16 & 62.60 \\
\hline 39 & 14 & $\begin{array}{l}\text { It is distinguished by comprehensiveness, variety } \\
\text { and balances between theoretical and applied } \\
\text { aspects }\end{array}$ & 3.15 & 62.42 \\
\hline 33 & 15 & Develops social ,cultural and health skills & 3.13 & 61.87 \\
\hline 38 & 16 & $\begin{array}{l}\text { Includes summaries to emerge main thoughts and } \\
\text { concepts in the end of each chapter }\end{array}$ & 3.12 & 61.21 \\
\hline 35 & 17 & $\begin{array}{l}\text { The content is integrated with other text books for } \\
\text { the same class }\end{array}$ & 3.09 & 60.97 \\
\hline 25 & 18 & $\begin{array}{l}\text { The subjects and chapters are related and integrated } \\
\text { with each other }\end{array}$ & 3.06 & 60.60 \\
\hline 40 & 19 & Its methods of presentation encourages self-learning & 3.05 & 57.52 \\
\hline 26 & 20 & $\begin{array}{l}\text { It is distinguished by preciseness, ,clarity and free } \\
\text { from errors }\end{array}$ & 3.03 & 53.84 \\
\hline 42 & 21 & Indicates other learning resources & 2.88 & 53.52 \\
\hline 41 & 22 & Balances the number of book chapters pages & 2.69 & 53.84 \\
\hline \multicolumn{3}{|c|}{ Arithmetic mean for the field of items weight } & 3.18 & 63.55 \\
\hline
\end{tabular}

From the analysis of the data of Table (4), it appears that the field of improving the scientific content quality came in fifth, with an arithmetic mean of 63.55, and that ten criteria were included in the book at a high degree. First came criterion 24 (consistent with the level of students and their mental abilities), criterion 31 came second (Its presentation suggests an appropriate teaching method). Followed by criteria 34 (Without repetition and elaboration). Then standard 22 (achieving educational aims). Followed by criterion 21 (Matching with the 
philosophy of the book and society). Then criterion 27 (characterized by scientific and technical modernity). Followed by criterion 36. (includes illustrative examples and proofs). Then criterion 32 (develops students' creative abilities and scientific thinking skills). Then criterion 29 (taking into account the students' past experiences and integrated with them). Followed by criterion 37 (taking into account the principle of flexibility, amenability).

This may be due to the presence of one of the authors with specialization in curricula and teaching methods. This was reflected in the way the content was presented, avoiding unjustified repetition, and the content's connection to the goals and needs of society, with adding examples that illustrate the content and related to the students' previous experiences.

The other criteria included a medium and weak degree. The researcher believes that the reason for this may be due to the novelty of authorizing the book. The difference between the number of chapter pages is due to the importance of some chapters such as genetics according to the authors' opinion.

Table (5) shows the responses of the sample of teachers and supervisors to the field of improving the quality criteria of activities

\begin{tabular}{|l|l|l|l|l|}
\hline Ser. & $\begin{array}{l}\text { grad } \\
\text { e }\end{array}$ & criteria & $\begin{array}{l}\text { Weighted } \\
\text { average }\end{array}$ & $\begin{array}{l}\text { Percentag } \\
\text { e Weight } \\
\text { Went }\end{array}$ \\
\hline 48 & 1 & Suits the scientific content & 3.28 & 65.68 \\
\hline 45 & 2 & Develop students skills of scientific thinking & 3.11 & 62.30 \\
\hline 47 & 3 & Suits the students' abilities and experiences & 3.11 & 62.24 \\
\hline 49 & 4 & $\begin{array}{l}\text { Takes into account students, individual } \\
\text { differences }\end{array}$ & 3.06 & 61.21 \\
\hline 44 & 5 & Contribute in achieving the objectives & 3.04 & 60.73 \\
\hline 50 & 6 & Easy to implement & 3.02 & 64.48 \\
\hline 54 & 7 & $\begin{array}{l}\text { Help the students to apply what they learn in new } \\
\text { attitudes }\end{array}$ & 2.96 & 59.21 \\
\hline 51 & 8 & Suit the time dedicated to implement & 2,96 & 59.15 \\
\hline 55 & 9 & Evoke the motivation in students & 2.92 & 58.31 \\
\hline 53 & 10 & attractive and exciting & 2.09 & 57.95 \\
\hline 46 & 11 & Help in researching and exploring & 2.89 & 57.76 \\
\hline 56 & 12 & Encourage cooperative education & 57.70 \\
\hline 52 & 13 & Distributed in balance among the book chapters & 2,78 & 57,34 \\
\hline 57 & 14 & $\begin{array}{l}\text { Including methods devices, and education } \\
\text { subjects }\end{array}$ & 2.72 & 54.44 \\
\hline 43 & 15 & Provide sufficient education activities & 2,72 & 45.32 \\
\hline Arithmetic mean for the field of items weight & 2.96 & 54.25 \\
\hline
\end{tabular}

Table (5) shows that the field of activities came last, with an arithmetic mean of (59.25). The book included the following criteria with a high degree. Criterion 47 came first (related to scientific content). Followed by criterion 48 (easy to implement). Then criterion 50 (taking into account the differences) individual students). Then Standard 49 (corresponds to the time allotted for its implementation). Then Standard 51 (corresponds to students' abilities and experiences), The researcher attributes this to the weak focus on activities due to the lack of their presence in the ministerial exams. The students, focus on the their achievement not on the practical one. 
Table (6) shows the responses of the sample of teachers and supervisors to the criteria for improving the quality of photos, figures and tables

\begin{tabular}{|l|l|l|l|l|}
\hline Ser. & grade & criteria & $\begin{array}{l}\text { Weighted } \\
\text { average }\end{array}$ & Percentage \\
\hline 62 & 1 & Related to the scientific material and express it . & 3.56 & 71.30 \\
\hline 60 & 2 & Suitable for students ages & 3.56 & 71.12 \\
\hline 61 & 3 & matching the place with their topic & 3.48 & 69.61 \\
\hline 63 & 4 & $\begin{array}{l}\text { Contribute in achieving the objectives and the } \\
\text { content }\end{array}$ & 3.46 & 69.12 \\
\hline 64 & 5 & $\begin{array}{l}\text { proportional to the size and space of the subject. } \\
\text { Help the student to understand the subject and } \\
\text { explain abstract thoughts }\end{array}$ & 3.37 & 67.31 \\
\hline 59 & 7 & Introduced in clear colored form & 3.27 & 66.77 \\
\hline 68 & 8 & $\begin{array}{l}\text { Take into account the individual differences of the } \\
\text { students }\end{array}$ & 3,26 & 65.38 \\
\hline 66 & 9 & Support positive trends of the students & 3.17 & 63.38 \\
\hline 58 & 10 & $\begin{array}{l}\text { Introduced in sufficient and various numbers and } \\
\text { in schematic stereoscopic forms }\end{array}$ & 3.17 & 63.32 \\
\hline 69 & 11 & Invoke the students interests & 3.16 & 63.26 \\
\hline 65 & 12 & Accurate and modern & 3,15 & 63.08 \\
\hline Arithmetic mean for the field of items weight & 3.33 & 66.5 \\
\hline
\end{tabular}

The analysis of data in table (6) shows that the field of improving the quality of photos, figures and tables came in the second place with an arithmetic of (66.57). The following criteria came in the higher degree. criterion 62 came first(related to the scientific material and expressing it) Followed by criterion 60 (appropriate for the age of students). criterion 61 (matching the place with their topic). criterion 63 (contribute to the achievement of objectives and content). criterion 64 (appropriate to the size and space of the topic). criterion 67 (help students understand the material and clarify abstract ideas).

The researcher believes that the reason for this may be due to modern technologies, the spread of the Internet and modern sources that came into Iraq.

The others, concern with the interest factor for the scientific material motivated them in adding these photos, figures and tables. The other criteria came in moderate and weak degrees. This may due to the back focus on the scientific material. The 30Dimension photos need to highly- technology facilities.

Table (7) shows the responses of the sample of teachers and supervisors to the criteria for improving the quality of evaluation methods

\begin{tabular}{|l|l|l|l|l|}
\hline Ser. & grade & criteria & $\begin{array}{l}\text { Weighted } \\
\text { average }\end{array}$ & $\begin{array}{l}\text { Percentage } \\
\text { Weight }\end{array}$ \\
\hline 75 & 1 & Formulated in clear an understandable form & 3.48 & 69.61 \\
\hline 83 & 2 & $\begin{array}{l}\text { the diversity of knowledge filed questions: } \\
\text { Remembering, understanding, applying, analyzing, } \\
\text { synthesizing, evaluating }\end{array}$ & 3.41 & 68.22 \\
\hline 73 & 3 & questions variety between subjective and objective & 3.41 & 68.16 \\
\hline 74 & 4 & Include the whole scientific material & 3.40 & 68.10 \\
\hline 70 & 5 & Consistent and related to the objectives & 3.36 & 67.25 \\
\hline 79 & 6 & $\begin{array}{l}\text { Help the teacher to determine the common mistake } \\
\text { thoughts }\end{array}$ & 3.33 & 66.65 \\
\hline 82 & 7 & $\begin{array}{l}\text { Include post tests in the end of each lesson and } \\
\text { chapter }\end{array}$ & 3.31 & 66.10 \\
\hline
\end{tabular}




\begin{tabular}{|c|c|c|c|c|}
\hline 78 & 8 & $\begin{array}{l}\text { Develop the students' abilities and invoke their } \\
\text { thinking }\end{array}$ & 3,26 & 65.20 \\
\hline 76 & 9 & $\begin{array}{l}\text { Take into account cognitive, emotional and skilled } \\
\text { aspects }\end{array}$ & 3.25 & 65.08 \\
\hline 77 & 10 & $\begin{array}{l}\text { Help the students to research, investigate and } \\
\text { review the materials }\end{array}$ & 3.23 & 64.59 \\
\hline 71 & 11 & $\begin{array}{l}\text { Take into account the individual differences of the } \\
\text { students }\end{array}$ & 3.22 & 64.41 \\
\hline 72 & 12 & $\begin{array}{l}\text { Measure It measures the extent to which objectives } \\
\text { have been achieved }\end{array}$ & 3,22 & 64.41 \\
\hline 84 & 13 & Take into account the test planning & 3.17 & 63.32 \\
\hline 81 & 14 & $\begin{array}{l}\text { Includes within tests during introducing of each } \\
\text { lesson and chapter }\end{array}$ & 3.01 & 60.18 \\
\hline 80 & 15 & $\begin{array}{l}\text { Include primary tests in the beginning of each } \\
\text { lesson and term }\end{array}$ & 2.34 & 46.86 \\
\hline \multicolumn{3}{|c|}{ Arithmetic mean for the field of items percentage } & 3.33 & 65.22 \\
\hline
\end{tabular}

The data in Table (7) indicate that the field of evaluation methods ranked fourth, with an arithmetic mean of (65.22). It included the following criteria with a high degree, as criterion 75 (formed clearly and understandably) came first. Criterion 83 (the diversity of knowledge filed questions: Remembering, understanding, applying, analyzing, synthesizing, evaluating)came second. Criterion 73 (questions variety between subjective and objective). Followed by criterion 74 (includes the scientific material). Then criterion 70 (consistent and related to the objectives). Criterion 79 (helping the teacher determine Commonly Wrong Ideas), followed by criterion 82 (includes post-tests at the end of each lesson and chapter). This is due to the book authors' ability to formulate aims clearly, pay attention to the levels cognitive aspect, and diversify questions that measure the objective aims.

The book included the rest of the criteria with moderate and weak degrees. The researcher attributed this to the book's reliance on post questions without paying attention to the anti and withen questions, which is a traditional method, and the book's interest in the cognitive aspect of the assessment to take into account from of the ministerial tests.

Table (8) shows the responses of a sample of teachers and supervisors to the field of for improving the quality of artistic editing criteria.

\begin{tabular}{|l|l|l|l|l|}
\hline Ser. & grade & criteria & $\begin{array}{l}\text { Weighted } \\
\text { average }\end{array}$ & $\begin{array}{l}\text { Percentage } \\
\text { Weight }\end{array}$ \\
\hline 88 & 1 & $\begin{array}{l}\text { Includes the names of the writers, name of } \\
\text { publishing house and year of printing }\end{array}$ & 4.26 & 85.26 \\
\hline 92 & 2 & $\begin{array}{l}\text { The distance between the words and lines is } \\
\text { consistent with }\end{array}$ & 4.05 & 80.97 \\
\hline 91 & 3 & $\begin{array}{l}\text { The size of letters is matching with the age of the } \\
\text { students }\end{array}$ & 3.79 & 79.40 \\
\hline 95 & 4 & $\begin{array}{l}\text { The number of lines matching with the size of } \\
\text { the page }\end{array}$ & 3.92 & 78.34 \\
\hline 96 & 5 & $\begin{array}{l}\text { The space of the footnotes } \\
\text { The main and branch titles are distinguished by } \\
\text { clarity and attractive for the learner and reader }\end{array}$ & 3.85 & 78.19 \\
\hline 93 & 6 & $\begin{array}{l}\text { The book's papers are characterized by } \\
\text { sharpness and smoothness }\end{array}$ & 3.83 & 76.62 \\
\hline 89 & 7 & The size of the book matches the students' ages & 3,76 & 75.23 \\
\hline 94 & 8 & The book colors are consistent & 3.51 & 70.21 \\
\hline 90 & 9 &
\end{tabular}




\begin{tabular}{|l|l|l|l|l|}
\hline 98 & 10 & $\begin{array}{l}\text { The book is designed by organized style that } \\
\text { encourages learning and teaching }\end{array}$ & 3.40 & 68.10 \\
\hline 99 & 11 & $\begin{array}{l}\text { Designed according to certain and affixed } \\
\text { manner }\end{array}$ & 3.38 & 67.67 \\
\hline 97 & 12 & The book is attractive & 3,38 & 67.55 \\
\hline 87 & 13 & The book cover expresses the content & 3.35 & 66.95 \\
\hline 86 & 14 & $\begin{array}{l}\text { The book cover is attractive for the student or } \\
\text { the reader }\end{array}$ & 3.18 & 63.69 \\
\hline 85 & 15 & The book cover is solid & 2.03 & 60.66 \\
\hline \multicolumn{2}{|l|}{ Arithmetic mean for the field of items percentage } & 3.65 & 73.06 \\
\hline
\end{tabular}

The field of the quality of the artistic editting of the biology book came in first place, and the arithmetic mean was (73.06), as it shown table (8). The following criteria got a high degree, as criterion 88 (includes the names of the authors, the name of the printing press and the year of printing) came first. Criterion 92 (consistency Space between words and lines) came second. Criterion 91 (the size of letters is matching with the age of the students) came third. Criterion 95 (the number of lines matching with the size of the page). Criterion 96 (the space of the footnotes), Criterion 93 (the headlines and subheadings are clear and attract the student or reader). Criterion 89 (the book's papers are characterized by sharpness and smoothness). Criterion 94 (the size of the book matches the students' ages).

The researcher attributes this to the craftsmanship of the designers, the use of advanced technical devices, and adherence to pre-approved design standards.

The other criteria got a moderate and weak degree. The researcher believes that the poor quality and bad quality cohesion of the papers are due to the printing press, while the weakness of the cover design may be attributed to the overlapping of colors and the selection of images.

\section{Conclusion}

The research reached a set of results stating the Biology book included most of the criteria of quality improvement. The field of artistic editing of the book came first, then the field of improving quality of images, figures and tables came second. The field of improving quality of educational objectives came third. The field of quality of assessment methods came fourth. The field of improving quality of scientific content came fifth. The field of quality Introduction came Sixth, and finely the field of improving quality activities came seventh. There was a weakness in the criteria of the improving quality of the introduction, the quality of activities, and the quality of the scientific content. These data's were obtained as a result of a survey of (331) teachers and specialist supervisors for the subject of biology book, which requires reconsidering the writing of the introduction to conform the philosophy of the book with modern global attitudes of education, motivate students to study the topics of the book, indicate the method of teaching. and meets the needs of students and the community. It should increase activities to be attractive and interesting. It helps search and explore. It encourages cooperative learning. It is distributed in a balanced manner over the chapters of the book. The scientific content of the book should include summaries an highlight the main concepts at the end of each chapter. The content should be integrated with other textbooks. Topics and chapters are linked to each other. Its presentation encourages self-learning with accuracy, clarity and error-free. It refers to other learning resources. The number of pages of the book chapters should be balanced.

The authors of the curriculum should adopt the criteria for improving the quality of the textbook that adopted by the current research, reconsider the organization of the content of the biology book for the sixth scientific class, pay attention to the emotional, and applied aspect of the textbook. 
The need to adopt collective authoring of textbooks and to involve the specialists of teaching methods.

\section{References}

Abbas etal,2011, An Entrance to the Methods of Research and Psychology, Almasira House for Publishing, Amman. p: 261.

Abdullah, Adel Mohammed, 2015, Management of Services Quality,1st edition, Alwaraq House, Amman. P: 168-169.

Alashqar, et al, 2007, the quality level in One of Quality Elements of Education Process from the Teachers and Supervisors Points of View, A research Submitted to Education Conference, Islamic University, Ghaza. P:3.

Alhariry ,Rafida,2011,Comprehensive Quality in Curriculums and Methods of Teaching . Almasira House for Publishing .Amman. p: 265.

Ali, Mohammed, 2007, Scientific Education and Teaching Science, Almasira House for Publishing. P: 15.

Alkhawalda, Mohammed ,2007,Basics of Building the Curriculums and Design of Scientific book ,2ed edition. Almasira, Amman. P: 11, 301.

Alqudhat, Mohammed Mahmood Mohammed and Alkhawalda, Salem Abdulazeez, 2016, They Level of Understanding Nature of Science according to NASTA standards in Teachers of Sciences in Jordan in the Light of some Variables ,M A Thesis, Al Albait University, College of Educational Sciences, Almafraq. P: 12.

Ben Shalwya ,kamalia and Sharfy Amaly, 2013, Quality as an Entrance to Improve the Performance in Public Institutions, Case Study, Alwahat mill Foundation ,College of Economic Sciences. Qasdy Merbah University, Algeria. P: 28.

Bloom, Benjamin S. 1981, Evolution to Improve Learning, McGraw- Hill, Inc., New York. P: 126.

Dahdoh, Lelia, 2018, The Role Quality management in Promote the Efficiency of Human Resources, Field Study in the Society of dried beans and Legumes, M A thesis in Sociology, Araby bin Almuhaidy University ,College of human Sociology and Science. P: 44.

Deming, J.W 1986, Out of Crises, Massachusetts Institute o Technology, Cambridge university Press, MA. P: 88.

Ebel Robert, 1972:Essentials of Education and Measurement, 2ed edition Englewood Cliffs, N.Y, Prentice Hall. p: 667.

Good Cartert .v., 1973,Dictionary of Education ,3rd edition ,Alexandria, ASCD. P: 51, 153.

Hammadat ,Mohammed Hassan ,2009,Education Curriculums, Theories', concepts, bases, Elemnts and evaluations, 1st edition Alhamid House for Printing, Amman. P: 199.

Harba, Amira Ibrahem, Arat Abdulameer Khalaf and Ali, Naefr Hady, 2015, Evaluationof Physics Book of the Scientific Fourth year According to Comprehensive Quality Standard from the Teachers and Supervisors Points of View, College of Basics Education for Education Sciences, University of Babel, issue No.23.Babel.p: 248.

Harris, Douglas, 2001, How to use Standards in the Classroom, Virginia, Alexandria. ASCD. P: 5.

Uda, Ahmed Suliman and fathy Melkawy,1992, the Basics of Scientific Research in Education and Human Science, Alkinany library, Amman. P: 345.

Iztok, Devetak \& Vorgince,2013, Critical Analysis o Science Textbooks Evaluating instruction of activeness ,Editor of Myint Swe Khine ,Science \& Mathematics Education Center, Curtin University ,Perth ,Australia ,Springer. P: 8-10. 
Jin-Hai Li, Alistair R. Anderson, Richard T. Harrison, 2003, Total quality management principles and practices in China, International Journal of Quality \& Reliability Management, Vol. 20 No. 9, Yorkshire. P: 8-9.

Malkova ,Zoya. A, 1989, The Quality of Mass Education, Prospects, Paris, UNESCO, Digital Liberary, Vol.19 No. https:undesco.org.ark:48223.Pf0000084158-ara. P: 36.

Mclancy, Eddie \& Atrill, Peter, 2007, "Management Accounting for decision makers", 5thEd., prentice Hall Co.

Ministry of Education,1984, The Amended of the Regulation of Secondary Schools No.(2) on 1977, Ministry of Education Printing House ,Baghdad.

Ministry of Education/ General Directorate for Education Planning, 2017, statistical Booklet, Baghdad.

Oliva,P.E.,2008, Developing the curriculum. New York. Longman. P: 18.

Toaima, Rushdy Ahmed ,2006, Comprehensive Quality in Education between Indicators of Distinguishing and Standard of Adopting the basics and Applications ,1st edition, Almasira House for Publishing. P: 25.

Ubiedat, Salman, 1999, Education Measurement and Evaluation, Jordanian University, College of Education, Amman. P: 45.

Ulian ,Shaher Rebhy ,2010, Curriculums of natural Sciences and Methods of Teaching them, The Theory and Application, 1st edition Almasira, Amman. P: 6.

Usielan, Bandar Bin Khalid Hassan,2011, Evaluation of Developed Science book from First Year intermediate School in the Light of Comprehensive Quality Standards Unpublishe MA Degree, UmAlqura, College of Education Mecca. P: 3.

Weetman, Pauline, 2006, "Management Accounting" 1st Ed., Pearson Education Limited.

Yousif fathy etal,2004, The Curriculums, Components, Design, and Development,1st edition, AlfiKer House, Amman. P: 504. 